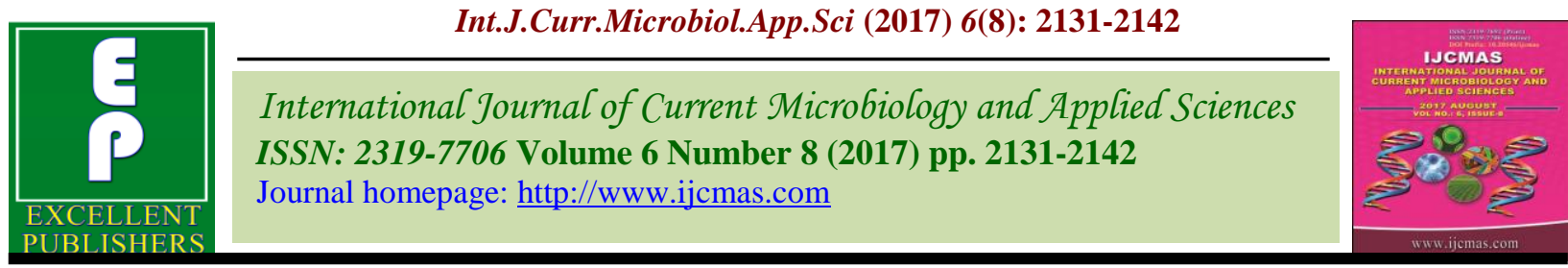

Original Research Article

https://doi.org/10.20546/ijcmas.2017.608.253

\title{
An Econometric Analysis on Groundnut Markets in India
}

\author{
R. Sangeetha ${ }^{1 *}$, M.S. $\operatorname{Raman}^{2}$ and S. Menaka ${ }^{3}$ \\ Department of Agricultural Economics, Centre for Agricultural and Rural Developmental \\ Studies, Tamil Nadu Agricultural University, Coimbatore -641 003 \\ *Corresponding author
}

\section{A B S T R A C T}

\begin{tabular}{|l|}
\hline Ke y w o r d s \\
$\begin{array}{l}\text { Groundnut, Time } \\
\text { series, Spatial } \\
\text { market } \\
\text { integration, Price. }\end{array}$ \\
\hline Article Info \\
\hline $\begin{array}{l}\text { Accepted: } \\
\text { 19 June 2017 } \\
\text { Available Online: } \\
\text { 10 August } 2017\end{array}$ \\
\hline
\end{tabular}

\section{Introduction}

Groundnut also known as peanuts, earthnuts, goobers, pinders and manila nuts is believed to be a native of Brazil before it moved to other parts of the world. In India, it was introduced from one of the Pacific Islands of China somewhere in the first half of the sixteenth century. Shelled groundnuts are basically used as seed, consumed as raw edible groundnuts or after transformation into "prepared" groundnuts (roasted, salted, flavoured, etc.) or into groundnut butter/ paste. The seeds can also be crushed for oil and a by-product, viz. groundnut meal (animal feed). Groundnut oil is used as quality cooking oil with a high smoke point $\left(440^{\circ} \mathrm{F}\right)$ and neutral flavour and odour. Presently, India along with China accounts for half of the world's groundnut production. Grown in tropical and subtropical areas, groundnut thrives between $25-28^{\circ} \mathrm{C}$ and under $500-\mathrm{mm}$ rainfall in loamy and black soil. India ranks second in the world (after China) in groundnut production. The three southern states of Andhra Pradesh, Tamil Nadu, Karnataka and the western state of Gujarat together accounted for close to 80 per cent of the annual output in India. About 70-75 per cent of the crop is Kharif, grown during rainy season, (planted during May-July and harvested in September-mid December). In the Rabi (winter) season planting is during mid-September to November and harvesting during March and April. Crop failures occur periodically due to inadequate or excessive rain or unfavorable rainfall distribution. 
Thus, being largely a kharif crop, monsoon variation fluctuates groundnut production in the country.

Major producers of groundnut in the world

Groundnut is grown in more than 100 countries in the world. As per FAO statistics, India, till 1991 was the largest producer of groundnuts in the world, but by 2011 China overtook India and now holds the first position. The twenty major producers of groundnut together accounted for around 90 per cent of the total world production. The top five main producers China, India, Nigeria, USA and Indonesia contributed 74 percent to the total world production (Fig. 1).

Among the 10 major producers large variations exist in yield levels. Yield levels of USA and China are almost three times the world average yield and many major producing countries have yield levels less than the world average (1.6 tonnes/ha). India contributed around 19 percent of world production but the yield level is less than the world average yield and visibly less than that of China and USA the other two major producers of groundnuts in the world. China has been able to double the yield levels in two decades from 1.50 to 3.60 tonnes/ha (between 1980-81 and 2015-16), a factor that has presumably contributed in China's emergence as the largest producer in the world. However, none of the major ten producers of groundnut figure in the list of countries recording the highest yields. The highest yield (tonnes per hectare) is recorded in China (3.6), USA (3.8), Argentina (2.19), Vietnam (1.86), Indonesia (1.83) and Indonesia (1.83) (FAO Statistics).

Granger (1981) studied the econometric methods are not always more accurate than time-series models, they help in understanding causal relationships between variables and can provide evidence of the validity of economic theory. Moreover, all forecasting methods require the use of qualitative judgement. Simple methods based on sound judgement frequently give better forecasts than complex and sophisticated methods. Thus, a point forecast is of limited use and tends to be associated with uncertainty.

Engle (1987) studied the error correction model is generally thought to be isomorphic to integrated data and the modeling of cointegrated processes, and as such, is considered in-appropriate for stationary data. Given that many political time series are not integrated, analysts are unable to take advantages of the error correction model's ability to capture both long and short-term dynamics in a single statistical model. We use analytical results to demonstrate that error correction models are appropriate for stationary data.

Goodwin (1991) studied the spatial linkages in regional cattle markets using cointegration tests of regional price series. Several markets were not cointegrated over the 1980 through 1987 period. However, significant increases in cointegration of several regional livestock markets are observed through the 1980s. The increased cointegration parallels significant structural changes in the livestock industry. A formal analysis of market characteristics reveals that distances between markets, industry concentration ratios, market volumes, and market types have significant influences on cointegration relationships between markets.

Keeping the above aspect in view an attempt is made in this paper to analyze the marketing efficiency of groundnuts market at regional levels, with the overall objective the present study was carried out with the following specific objectives. 
1. To analyze the Spatial and temporal aspects of area, production, yield and price aspect of groundnut cultivation in India.

2. To analyses the direction of causality among Groundnut markets.

3. To estimate the price transmission within the Domestic Groundnut markets

4. If the markets are integrated, a given change in price of Groundnut in one market should reflect in change in prices of Groundnut in other markets.

\section{Materials and Methods}

\section{Selection of markets}

The present study was based on secondary data. The time-series data on area, production, productivity and domestic price were collected from published sources of the indiastat for the period of 65years (from 1950-51 to 2014-2015). In India, Andhra Pradesh, Gujarat, Tamil Nadu and Karnataka put together contributes more than 80 per cent of the country's total Groundnut production, so markets from Andhra Pradesh, Gujarat, Tamil Nadu and Karnataka states were selected purposively. Among the various regulated markets, a representative market was selected from each state based on arrivals, period of existence, participation of traders etc. and monthly price data for groundnut were collected from each selected regulated market from January 2005 to August 2016.

\section{An overview of groundnut market}

Groundnut is the single largest source of edible oils in India and constitutes roughly about 50 per cent of the total oilseed production. India grows about nine million tons of groundnuts (in shell) currently. Four types of groundnut were grown in India, though marketed under many names; e.g.,
Coromandel, Bold, Khandesh (or Peanuts), and Red Natal. The prices of Groundnut and Groundnut products in the country and states are mainly centered on two major Groundnut products viz., Groundnut and Groundnut oil. The price of Groundnut is usually influenced by the price of Groundnut oil prevailing in the wholesale markets. The factors that determine the price of Groundnut and Groundnut products are also associated with the growers, oil industry, and consumers. Variations in quality of matured Groundnut, size of shell, Groundnut content, oil content, marketing cost, marketing methods of fresh Groundnut production are also deciding factors for the price received by the Groundnut farmers. The Groundnut shells produced on farm move through many agencies like farmers or producers, collectors, wholesalers and processors, before reaching the consumer in various forms. The involvement of these agencies and number of agencies involved in the marketing channels are also deciding factors of Groundnut and Groundnut oil prices. The size of Groundnuts matters much in fixing price of matured nuts, as bigger shells usually yield more Groundnut.

This crop has diverse uses and consumption pattern varies widely from state to state. The size, shape and maturity of the nuts have more considerations of consumer preference. The bulk of the processed groundnut oil goes to the consumer in filtered form, and only a small portion is refined. The small part of groundnut oil routed through refineries mainly goes through brokers. The channel is refineries-wholesalers-retailers-consumers.

The bulk of the oil, which is only filtered, goes through the brokers-wholesalersretailers-consumers for sale within the state. For outstation sales, the channel is brokercommission agent-wholesaler-retailersconsumers. 


\section{Market integration}

The area and production of Groundnut is on the increase in India as confirmed by positive compound annual growth rates during 19502015. The growth rates during 2010-11 to 2015-16 are 5.01 for area and 4.98 for production. To maintain the growth rate, it is essential that a farmer should receive remunerative prices. They should get a better share of consumers' rupee paid for Groundnut oil and Groundnut. This is possible only when marketing efficiency is of high order. Market integration analysis over space and form are the major tools to verify the marketing efficiency.

If price changes in one market are fully reflected in alternative market, these markets are said to be spatially integrated [Goodwin and Schroeder (1991)]. Prices in spatially integrated markets are determined simultaneously in various locations, and information of any change in price in one market is transmitted to other markets [Gonzalez-Rivera and Helfand (2001)]. Markets that are not integrated may convey inaccurate price signal that might distort producers marketing decisions and contribute to inefficient product movement [Goodwin and Schroeder (1991)], and traders may exploit the market and benefit at the cost of producers and consumers.

\section{Price transmission analysis}

Price transmission analysis measures the effect of prices in one market on prices in another market. This analysis can be used to study the relationship between domestic price and regional prices for Groundnut and prices in four different local markets. The output of price transmission analysis helps to understand the following points - Is there a long-term relationship between the two markets, Do prices in market ' $\mathrm{A}$ ' influence those in market ' $\mathrm{B}$ ', the reverse, or do they both influence each other, If the price in one market changes how much will it cause the other price to change in short run and if the price in one market changes how much will it cause the other price to change in the long run (Rivera, 2007). In the context of two domestic prices, it tells us whether market ' $A$ ' is influencing market ' $\mathrm{B}$ ', or ' $\mathrm{B}$ ' is influencing ' $A$ ', or if both are influencing each other. This causation analysis helps in understanding and describing trends in local prices.

\section{ADF test}

Prior to testing for co integration, the price series are first tested for their order of integration, since a necessary condition for co integration is that the series are integrated of the same order. The augmented DickeyFuller (ADF) test is used to test for the order of integration. To test unit root, the ADF test is conducted based on the following regression equation:

$\Delta Y_{t}=\beta_{1}+\delta Y_{t-1}+\alpha_{i} \sum \Delta Y_{t-1}+e_{t}$

[t-1: 1 month lagged price and $\Delta$ : differenced series]

$\mathrm{Y}_{\mathrm{i}}$ denoted the price series of markets (AP, TAN, GUJ, KAR Groundnut price series).

If the coefficient $\delta$ is not statistically different from zero, it implies that the series have a unit root, and, therefore, the series is non- stationary. To verify that the first differenced price series is indeed stationary, ADF unit root tests are used. The null hypothesis of non-stationary is tested using a t-test. The null hypothesis is rejected if the estimated variable is significantly negative. Once the variables are checked for stationary and are of the same order, integration between them can be tested 


\section{Market integration}

Testing for market integration is central to the design of any agricultural price policy in many developing countries and has been an area of abiding research interest. This literature can be divided into three broad categories. Until recently two broad approaches had been used to investigate market integration: (i) that devised prior to the use of co integration techniques (ii) those using co integration methods of the EngleGranger variety, and (iii) those using Johansen maximum-likelihood techniques (Johansen, 1988). To the extent that agricultural prices tested are non-stationary, the latter technique is more appropriate.

\section{Engle-granger causality}

An autoregressive distributed lag (ADL) model for the Granger-causality test was developed following Engle and Granger (1987) specification provided below:

$$
P_{t}^{1}=\alpha+\beta_{0} T+\sum_{j=1}^{j} \beta_{j} P_{t-j}^{1}+\sum_{k=1}^{k} h_{k} P_{t-k}^{2}+\varepsilon_{t}
$$

where $T$ is the time trend, $\varepsilon_{t}$ is the error term.

Lags for the ADL model were selected to minimize the Akaike's Information Criterion. Granger causality tests were specified as:

$$
\begin{aligned}
& P_{t}^{1}=\alpha+\beta_{0} T+\sum_{j=1}^{j} \beta_{j} P_{t-j}^{1}+\sum_{k=1}^{k} h_{k} P_{t-k}^{2}+\varepsilon_{t} \\
& H_{0}: h_{1}=h_{2}=\ldots=h_{k}=0 \\
& P_{t}^{2}=\delta+\phi_{0} T+\sum_{j=1}^{j} \Omega_{j} P_{t-j}^{1}+\sum_{k=1}^{k} \varphi_{k} P_{t-k}^{2}+v_{t} \\
& H_{0}: \varphi_{1}=\varphi_{2}=\ldots=\varphi_{k}=0
\end{aligned}
$$

\section{Co-integration}

Co integration means that despite being individually non-stationary, a linear combination of two or more time series can be stationary. The series that satisfy this requirement are said to be co-integrated.

Following Granger (1981), a time series $\mathrm{x}_{\mathrm{t}}$ which has a stationary, invertible, nondeterministic ARMA representation after differencing $d$ times is integrated of order $d$ and is denoted by $x_{t} \sim l(d)$. The components of the vector $x_{t}$ are said to be co integrated of order $d, b$, denoted CI $(\mathrm{d}, \mathrm{b})$, if all the components of $x_{t}$ are $\mathrm{I}(\mathrm{d})$; there exists a vector ' $\mathrm{x}_{\mathrm{t}}$ is $1(\mathrm{~d}-\mathrm{b}), \mathrm{b}>0$

The vector is then called a co integrating vector. A necessary condition for co integration is that the data series for each variable involved exhibit similar statistical properties, that is, to be integrated to the same order with evidence of some linear combination of the integrated series.

Johansen (1988) developed a multivariate system of equations approach, which allows for simultaneous adjustment of both or even more than two variables. Johansen's approach is also widely used in many bivariate studies as it has some advantages to the single equation approach. First, the multivariate system of equations approach is more efficient than the single equation approach, i.e., it allows estimating the co integration vector with smaller variance. The second advantage of the multivariate approach is that in the simultaneous estimation it is not necessary to presuppose exogeneity of either of the variables.

\section{Error correction model}

Although price transmission analysis is a useful tool for understanding and predicting price trends, it only tells us about the relationship between two prices over time. It does not tell us why the price transmission is 
strong or weak, fast or slow (Engle and Granger, 1987). This interpretation can only be done with local knowledge of transportation routes, seasonal flows in staple foods, trade and agricultural marketing policies, the availability of foreign exchange and credit, the ease of obtaining permits, and the competition for overland freight, among other factors.

\section{Results and Discussion}

The compound annual growth rates (CARGs) of area, and production of groundnut in India were estimated and presented in table 2 . It may be noted that highest growth in production was registered in the year 20102016. The sixties and Seventies are marked by a negative growth in area and production overall, the growth of area of groundnut is negative and the production of Groundnut is positive in India over the last sixty years implying that the area was reduced due to the failure of monsoon and most of the states receiving very less rain, the crop as well as the quality is seriously affected. The details of area and production of Groundnut in different states of India during 2014-15 are furnished in table 3. It may be noted that Gujarat ranks first in area and production followed by Andhra Pradesh and Tamil Nadu. Andhra Pradesh has higher area comparing Tamil Nadu but the production is more in Tamil Nadu. The data reveal that more than 80 percent of production is contributed by Southern States alone while the oil products are used throughout India. The production of groundnuts in the State of Andhra Pradesh has been more or less consistent over the years unlike in Gujarat. In fact, Gujarat being one of the major groundnuts producing states, volatility of production has been a major threat to the groundnut industry in the country. On the other hand, two southern States, Tamil Nadu and Karnataka have steadily picked up in the rate of production over the years

\section{Market integration}

To verify level and first differenced price series were indeed stationary, Augmented Dickey-Fuller (ADF) unit root test was used. The ADF test results are presented for the period Jan' 2005 to December'2015 (Table 4). The equations were estimated with an intercept and time trend. The results are presented in table 1 for Augmented DickeyFuller (ADF) unit root tests for each series. The null hypothesis of non - stationarity was tested based on the critical values reported by MacKinnon. All the price series appeared non stationary in the levels, but all the series were stationary after taking first differences. After confirming the currency exchange rates were stationary in their first differences, co integration between the commodity futures was tested using Johansen's maximum likelihood procedure. The bivariate co integration technique of Engle and Granger was also tested for the presence of long run relationship existing between groundnut price in different states.

\section{Granger casualty test}

The causal relationship among the markets price of major Groundnut markets in India were approached through Granger's Causality technique and presented in table 5. It could be seen that existence of mostly bidirectional causality as well as unidirectional causality markets among groundnut of Tamil Nadu. The unidirectional relationship was found for the pair of Tamil Nadu and Gujarat markets indicates that price of Gujarat market influence the price of Tamil Nadu market whereas, the price of Tamil Nadu market does not influence the price Gujarat market during the investigation period. Similarly, unidirectional causality was exerted on Gujarat price by Andhra 
Pradesh and Tamil Nadu price by Andhra Pradesh. Karnataka and Tamil Nadu exerted bidirectional causality among them (Fig. 2). Thus a strong integration of major groundnut markets in India is confirmed that the price of one market influence the price of other markets through the result of the study. The test for causality is based on F statistics that is calculated by using unconstrained and constrained forms,

$\left.\mathrm{F}=\left\{\mathrm{SSE}_{\mathrm{r}}+\mathrm{SSE}_{\mathrm{f}}\right) / \mathrm{m}\right\} /\left\{\mathrm{SSE}_{\mathrm{f}} /(\mathrm{T}-2 \mathrm{~m}-1)\right\}$,

Where $\mathrm{SSE}_{\mathrm{r}}$ and $\mathrm{SSE}_{\mathrm{f}}$ are residual sum of squares of the reduced and full models respectively; $\mathrm{T}=$ total number of observations, and $\mathrm{m}=$ number of lags.

\section{Results of Jahansen's multiple cointegration analysis}

Since all the price series are non-stationary at level form and stationary at first difference level, Johansen cointegration test can be applied to analyze the long run equilibrium among the groundnut markets. The results of the analysis show that there is at least two co integration at 5 per cent level of significant (Table 6). Hence, it is concluded that long run equilibrium exists among the four major markets. Any shocks in these markets would affect the prices of the other markets.

\section{Vector error correction model}

For the present study, the Vector Error Correction Mechanism (VECM) was adopted to analyze the long run association between the markets under cointegration framework. Accordingly, VECM were computed and the results are presented in table 7 . The estimates of error correction coefficients for the first cointegration equation confirmed that the Tamil Nadu market came to equilibrium under short run when compared to markets. The speed of adjustment for short run equilibrium by the Tamil Nadu market was rapid as seen from the error correction equation since the Monthly price series is taken. But under long run, the major groundnut markets were influenced by their own lag as well as lag of other prices of other markets in India. There was a long-run co integration relationship between Tamil Nadu markets with other markets as the co integration coefficient for Tamil Nadu is Positive and significant at one per cent level. This indicates that the groundnut price of the Tamil Nadu market can adjust to the equilibrium point in long-run by 0.24 per cent due to any shock in the other markets.

In conclusion, groundnut plays a crucial role in the world economy particularly in Indian economy. In India considerable loss in groundnut production due to delayed sowing, frequent drought and uneven distribution of rainfall demands the acute need for short duration photo insensitive varieties suitable for various production environments. The domestic groundnut markets are highly integrated. Price transmission among domestic groundnut market is proved since it had long run association with the domestic markets. Results of the time series econometric analyses confirmed that domestic groundnut markets were integrated with international groundnut market and the world prices are transmitted to the domestic markets. Results of Johansen's multiple cointegration tests revealed that the domestic groundnut markets of Gondal, karnool, devangere and Tindivanam are integrated with at least one co integration vectors. 
Table.1 Major groundnut producing countries of the world in 2015

\begin{tabular}{|l|c|c|c|c|}
\hline Country & $\begin{array}{c}\text { Production } \\
\text { (million } \\
\text { tonnes) }\end{array}$ & $\begin{array}{c}\text { Percentage to } \\
\text { world } \\
\text { production }\end{array}$ & $\begin{array}{c}\text { Rank (as per } \\
\text { production) }\end{array}$ & $\begin{array}{c}\text { Yield } \\
\text { (tonnes per } \\
\text { hectare) }\end{array}$ \\
\hline China & 16.90 & 37.43 & 1 & 3.6 \\
\hline India & 4.6 & 18.91 & 2 & 1.13 \\
\hline Nigeria & 0.35 & 10.31 & 3 & 1.64 \\
\hline USA & 1.64 & 4.41 & 4 & 3.38 \\
\hline Indonesia & 1.13 & 3.04 & 5 & 1.83 \\
\hline Myanmar & 0.96 & 2.57 & 6 & 1.41 \\
\hline Sudan & 1.41 & 1.51 & 7 & 0.80 \\
\hline Viet Nam & 0.48 & 1.30 & 8 & 1.86 \\
\hline Ghana & 0.44 & 1.29 & 9 & 0.96 \\
\hline Argentina & 1.16 & 1.28 & 10 & 2.19 \\
\hline World & $\mathbf{1 3 . 2 8}$ & & & $\mathbf{1 . 6}$ \\
\hline
\end{tabular}

(Source:FAOSTAT, 2016)

Table. 2 Growth rates of area and production of groundnut in India

\begin{tabular}{|c|c|c|}
\hline Years & Area & Production \\
\hline 1950-51 to $1959-60$ & 1.04 & 3.89 \\
\hline $1960-61$ to $1969-70$ & 0.91 & -4.00 \\
\hline $1970-71$ to $1979-80$ & -1.38 & -0.34 \\
\hline $1980-81$ to $1989-90$ & 2.32 & 5.06 \\
\hline $1990-91$ to $1999-00$ & -3.76 & -0.49 \\
\hline $2000-01$ to $2009-10$ & -4.14 & -1.93 \\
\hline $2010-11$ to $2015-16$ & 5.01 & 4.98 \\
\hline $\mathbf{1 9 5 0 - 5 1}$ to $\mathbf{2 0 1 5 - 1 6}$ & $\mathbf{- 0 . 8 8}$ & $\mathbf{0 . 4 7}$ \\
\hline
\end{tabular}

Data Source: India stat, Ministry of Agriculture, Government of India

Table.3 State wise major area and production of groundnut in India (2014-15)

\begin{tabular}{|l|c|c|}
\hline States & $\begin{array}{l}\text { Area (in million } \\
\text { ha) }\end{array}$ & $\begin{array}{l}\text { Production (in } \\
\text { million tonnes) }\end{array}$ \\
\hline Tamil Nadu & 1.3 & 543.9 \\
\hline Karnataka & 0.9 & 221.1 \\
\hline Andhra Pradesh & 1.7 & 487.2 \\
\hline Maharashtra & 0.4 & 167.0 \\
\hline Gujarat & 1.8 & 2205.0 \\
\hline Rajasthan & 0.2 & 899.7 \\
\hline Madhya Pradesh & 0.1 & 380.0 \\
\hline India & $\mathbf{6 . 4 0}$ & $\mathbf{5 1 0 6 . 8}$ \\
\hline
\end{tabular}

Source: Ministry of Agriculture, Government of India (2014-15) 
Table.4 Results of unit root test (ADF test)

\begin{tabular}{|l|l|l|l|c|}
\hline Variable & \multicolumn{1}{|c|}{ Level } & \multicolumn{1}{|c|}{ Lags } & \multicolumn{1}{c|}{ First difference } & Lags \\
\hline LANP & -1.36 & $(1)$ & $-11.5888^{*} * *$ & $(0)$ \\
\hline LGUJ & -1.97 & $(1)$ & $-12.8297 * * *$ & $(0)$ \\
\hline LKAR & -1.88 & $(1)$ & $-6.4293 * * *$ & $(0)$ \\
\hline LTAM & -1.54 & $(1)$ & $-11.8199 * * *$ & $(0)$ \\
\hline
\end{tabular}

Note: Figures in parentheses are the number of significant lags

*** Significant at 1 per cent level

Table.5 Results of pairwise granger causality test

\begin{tabular}{|l|l|l|}
\hline Null hypothesis & F - statistic & P -value \\
\hline GUJ does not Granger Cause ANP & $1.081^{\mathrm{NS}}$ & 0.3424 \\
\hline ANP does not Granger Cause GUJ & $8.832^{* * *}$ & 0.0003 \\
\hline KAR does not Granger Cause ANP & $4.350^{* *}$ & 0.0149 \\
\hline KAR does not Granger Cause ANP & $2.523^{* *}$ & 0.0842 \\
\hline TAM does not Granger Cause ANP & $0.632^{\mathrm{NS}}$ & 0.5331 \\
\hline ANP does not Granger Cause TAM & $6.968^{* * *}$ & 0.0014 \\
\hline KAR does not Granger Cause GUJ & $2.376^{*}$ & 0.0970 \\
\hline GUJ does not Granger Cause KAR & $2.133^{\text {NS }}$ & 0.1227 \\
\hline TAM does not Granger Cause GUJ & $1.879^{\text {NS }}$ & 0.1570 \\
\hline GUJ does not Granger Cause TAM & $3.082^{* *}$ & 0.0493 \\
\hline TAM does not Granger Cause KAR & $0.576^{*}$ & 0.5636 \\
\hline KAR does not Granger Cause TAM & $6.204^{* * *}$ & 0.0027 \\
\hline
\end{tabular}

Note: *** Significant at 1 percent level; ** Significant at 5 percent level; * Significant at 10 percent level; NS -

Not significant

Table.6 Results of Johansen's multiple co-integration analysis for groundnut markets unrestricted cointegration rank test (Trace)

\begin{tabular}{|l|l|l|l|l|}
\hline \multicolumn{6}{|l|}{ Trace statistics of Series ANP,GUJ,KAR and TAN } \\
\hline No.of CE(s) & Eigenvalue & Statistic & Critical value & Probability \\
\hline None & 0.236367 & $67.97552^{* * *}$ & 47.856 & 0.0002 \\
\hline At most 1 & 0.146507 & $33.72771^{* *}$ & 29.797 & 0.0168 \\
\hline At most 2 & 0.092043 & $13.60857^{* *}$ & 15.494 & 0.0943 \\
\hline At most 3 & 0.010540 & 1.345728 & 3.841 & 0.2460 \\
\hline
\end{tabular}

Note: Critical values based on MacKinnon (1991); LR test indicated 2 co-integrating equation ***significant at 1 per cent level, **significant at 5 per cent level. 
Table.7 Reduced form vector error correction estimates

\begin{tabular}{|l|r|r|r|r|}
\hline $\begin{array}{c}\text { Error } \\
\text { Correction }\end{array}$ & D(ANP) & D(GUJ) & D(KAR) & \multicolumn{1}{c|}{ D(TAM) } \\
\hline ECM & -0.2451 & $\mathbf{0 . 3 7 6 4}$ & $\mathbf{0 . 2 0 8 1}$ & $\mathbf{0 . 2 9 2 6}$ \\
\hline & 0.0804 & 0.1213 & 0.1311 & 0.1434 \\
\hline & -3.0505 & 3.1024 & 1.5871 & 2.0698 \\
\hline D(ANP(-1)) & 0.0932 & 0.0485 & -0.3393 & -0.0933 \\
\hline & 0.1030 & 0.1555 & 0.1681 & 0.1839 \\
\hline & 0.9048 & 0.3119 & -2.0182 & -0.5072 \\
\hline D(ANP(-2)) & -0.0142 & $-\mathbf{0 . 2 3 9 2}$ & 0.0838 & -0.0715 \\
\hline & 0.1022 & 0.1543 & 0.1667 & 0.1824 \\
\hline & -0.1393 & -2.65060 & 0.5030 & -0.3920 \\
\hline D(GUJ (-1)) & -0.0121 & -0.1442 & -0.0409 & -0.0081 \\
\hline & 0.0589 & 0.0890 & 0.0962 & 0.1052 \\
\hline & -0.2064 & -1.6201 & -0.4254 & -0.0773 \\
\hline D(GUJ (-2)) & -0.0203 & -0.1796 & -0.1254 & -0.0780 \\
\hline & 0.0581 & 0.0877 & 0.0948 & 0.1037 \\
\hline & -0.3497 & -2.0465 & -1.3220 & -0.7525 \\
\hline D(KAR (-1)) & -0.0815 & 0.0749 & -0.2166 & $\mathbf{0 . 2 4 9 1}$ \\
\hline & 0.0627 & 0.0948 & 0.1024 & 0.1121 \\
\hline & -1.2985 & 0.7906 & -2.1145 & 2.000 \\
\hline D(KAR (-2)) & -0.1229 & 0.0774 & -0.11376 & -0.0093 \\
\hline & 0.0609 & 0.0920 & 0.0995 & 0.1088 \\
\hline & -2.0169 & 0.8416 & -1.1431 & -0.0863 \\
\hline D(TAM(-1)) & 0.0115 & 0.0499 & 0.1252 & -0.0284 \\
\hline & 0.0551 & 0.0832 & 0.0898 & 0.0984 \\
\hline & 0.2086 & 0.6001 & 1.3912 & -0.2889 \\
\hline D(TAM(-2)) & -0.0737 & 0.0412 & 0.1245 & $\mathbf{0 . 1 0 6 1}$ \\
\hline & 0.0546 & 0.0825 & 0.0891 & 0.0975 \\
\hline & -1.3493 & 0.5001 & 1.3966 & 2.6880 \\
\hline c & 24.23 & 29.81 & 18.10 & 24.22 \\
\hline R-squared & 0.1248 & 0.1407 & 0.1560 & 0.0801 \\
\hline Adj.R-squared & 0.0586 & 0.0758 & 0.0922 & 0.0105 \\
\hline AIC & 13.829 & 14.653 & 14.809 & 14.989 \\
\hline (KNe & & & \\
\hline & & & & \\
& & & &
\end{tabular}

$\{$ Note: Bold and italics are the significant variables

Note: ANP- Andhra Pradesh; GUJ- Gujarat; KAR- Karnataka; TAM- Tamil Nadu 
Fig.1 Major groundnut producing countries of the world in 2015

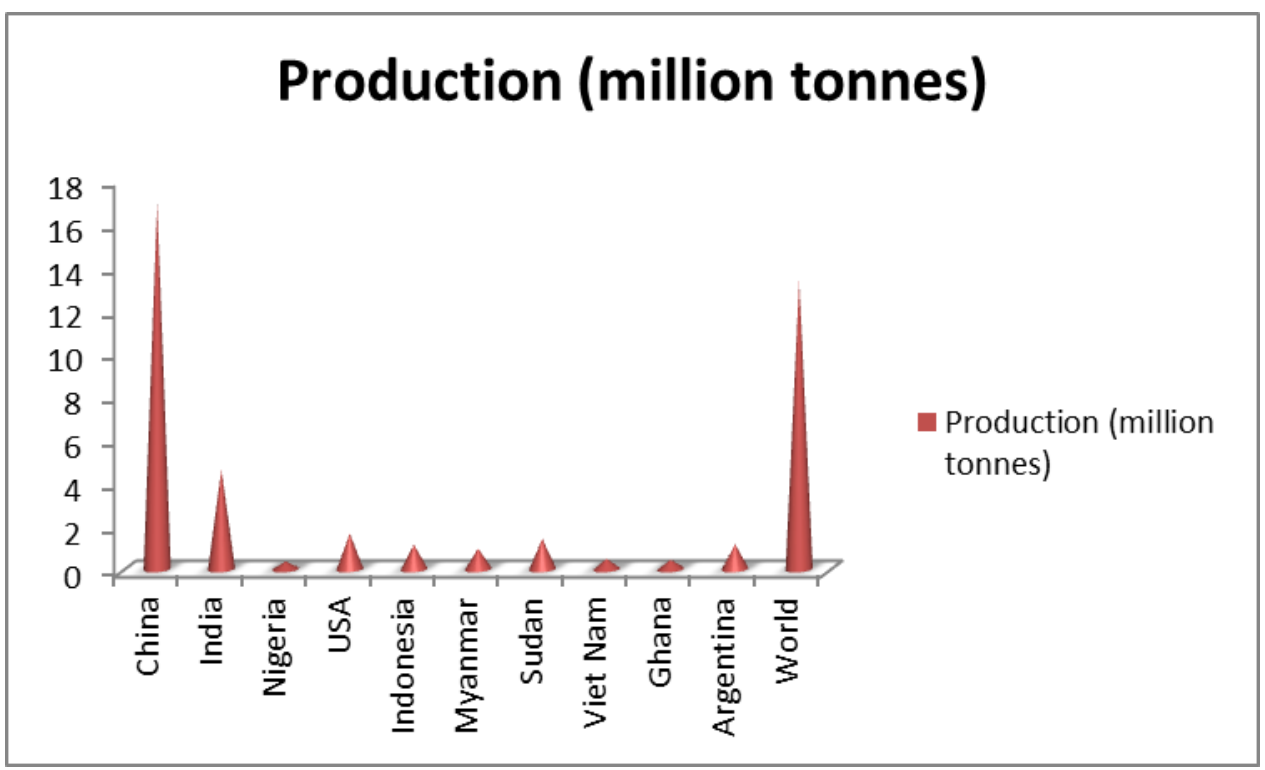

Fig.2 Influence of one market on the other on price formation

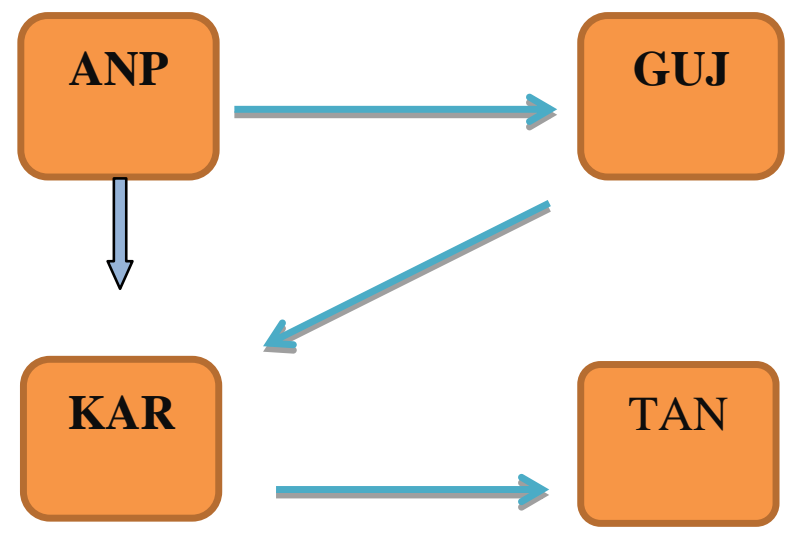

The existences of price volatility in the groundnut market are confirmed through GARCH estimation. High volatility in the groundnut price occurs in all the states. The price of groundnut was more than the average price during the months from May to July in all the states, except Karnool market in Gujarat. There exists long run equilibrium among the four major markets such as Andhra pradesh, Gujarat, Karnataka and Tamil Nadu. Vector Error Correction model showed that any shocks in these markets would affect the prices of the other markets each other. Also, Karnataka and Andhra pradesh markets have bidirectional relationship between each other and Tamil Nadu and Gujarat shows Unidirectional relationship between each other.

According to the Vector Error Correction model, it is known that the groundnut price of the Tamil Nadu market can adjust to the 
equilibrium point in long-run by 0.24 per cent due to any shock in the other markets.

\section{References}

Achaya, K.T. 1990. Oilseeds and Oilmilling in India - A Cultural and Historical Survey, Oxford and IBH, New Delhi.

Engle, R.F. 1982. Autoregressive conditional heteroskedasticity with estimates of Varience of UK inflation. Econometrica, 50(4): 978-1008.

Engle, R.F. and C.W.J. Granger. 1987. Cointegration and Error Correction, Representation, Estimation and Testing. Econometrica, 55(2): 251276.

Gonzalez-Rivera, G. and S.M. Helfand. 2001. The Extent, Pattern, and Degree of Market Integration: A Multivariate Approach for the Brazilian Rice Market. American J. Agric. Econ., 83: 576-92.

Goodwin, B.K. and T.C. Schroeder. 1991.
Cointegration Tests and Spatial Price Linkages in Regional Cattle Markets. American J. Agric. Econ., 73: 452-64.

Granger and C.A. Weiss. 1983. Time series analysis of error - correction models. In: Karlin, S. Amemiya, T. \& Goodman, L. eds. Studies in Econometrics, Time series, and Multivariate Statistics. New York: Academic Press.

Granger, C. 1981. Some properties of time series data and their use in econometric model specification. $J$. Econometrics, 16: 121-130.

Rivera, S.M. 2007. Market integration and efficiency in the Philippine Groundnut industry. FAO, Rome.

Vollrath, T.L. 2003. "North American agricultural market integration and its impact on the food and fiber system." Agriculture Information Bulletin No., 784, Market and Trade Economics Division, Economic Research Service, USDA, USA.

\section{How to cite this article:}

Sangeetha, R., M.S. Raman and Menaka, S. 2017. An Econometric Analysis on Groundnut Markets in India. Int.J.Curr.Microbiol.App.Sci. 6(8): 2131-2142. doi: https://doi.org/10.20546/ijcmas.2017.608.253 